\title{
Uusioersily
}

\section{Assessment of pain in people living with dementia at the end of life: a systematic review}

McAnee, G., Norwood, K., Rosato, M., \& Leavey, G. (2021). Assessment of pain in people living with dementia at the end of life: a systematic review. International Journal of Palliative Nursing, 27(2), 72-85.

https://doi.org/10.12968/ijpn.2021.27.2.72

Link to publication record in Ulster University Research Portal

\section{Published in:}

International Journal of Palliative Nursing

Publication Status:

Published (in print/issue): 02/04/2021

DOI:

10.12968/ijpn.2021.27.2.72

\section{Document Version}

Author Accepted version

\section{General rights}

Copyright for the publications made accessible via Ulster University's Research Portal is retained by the author(s) and / or other copyright owners and it is a condition of accessing these publications that users recognise and abide by the legal requirements associated with these rights.

\section{Take down policy}

The Research Portal is Ulster University's institutional repository that provides access to Ulster's research outputs. Every effort has been made to ensure that content in the Research Portal does not infringe any person's rights, or applicable UK laws. If you discover content in the Research Portal that you believe breaches copyright or violates any law, please contact pure-support@ulster.ac.uk. 


\begin{abstract}
Background: People with dementia may not receive the same quality of palliative care as those with other life-limiting conditions, particularly at end of life (EOL).

Aims: To understand the best way to examine pain for this population.

Methods: A systematic review of tools to assess pain in patients with dementia near the end of life. We searched PubMed; (Ovid) Medline; (Ovid) Embase; (EBSCO Host) CINAHL Plus; (ISI) Web of Science; (Ovid) Psycinfo; (Ovid) PsycArticles; and Scopus.

Findings: Fifteen articles were identified which were synthesised qualitatively.

Conclusion: There are a range of pain assessment tools which are appropriate for use for this population but fifteen studies used a formal tool. To improve the quality of research for measurement and management of pain in this population, a more robust approach is needed.
\end{abstract}

Keywords: Dementia, Palliative care, Pain tools, Pain assessment, End of Life

\title{
Key points:
}

- Most studies to assess pain measurement for people with dementia at end of life were done posthumously.

- There is a lack of data on what happens to pain levels after pain has been assessed and mitigation applied.

- There is an urgent need for well-validated pain assessment tools for this population.

- A quasi-experimental research design may provide an ethical approach to examine pain assessment in patients with dementia. 


\section{Introduction}

1.1 Pain assessment and treatment at end-of-life (EoL) in dementia

Dementia is a progressive, neurodegenerative disease characterised by a worsening ability to think, remember and learn (Dyer et al. 2018). It is a terminal illness (Alzheimer's Society 2014) and while some treatments can alleviate symptoms there is no cure. In the community it is not fully understood that dementia per se is life-limiting (O'Shea et al. 2015), with many people with dementia and their families unprepared for healthcare decision making at the end of life. This, combined with uncertainty surrounding the disease trajectory and difficulty in predicting prognosis at this end stage (O’Shea et al. 2015), makes effective symptom assessment crucial.

Smith (2000) lists the components of a good death as knowing when it is coming, having dignity and privacy, pain and symptom control, choice and control about where it occurs, access to information and expertise, access to spiritual or emotional support, access to hospice care in any location, control over who is present, ability to issue advance directives, time to say goodbye and avoidance of futile life-sustaining treatment. Holdsworth (2015) summarises the general consensus of a good death as one which is pain and symptom free, in which the patient has dignity and independence, in which family are present and are supportive and in which there is an awareness in health care professionals that death is imminent which is accompanied by good communication. Palliative care allows for the provision of quality care, especially relief from suffering to those with terminal illnesses (Morrison and Meier 2004; Seow et al. 2018). Typically suffering is seen as comprising physical pain, psychological distress and, in some cases, spiritual distress (Aminoff and Adunsky 2006). 
Although there is evidence that patients with dementia at EoL may experience the same symptom burden as those with cancer and other terminal illnesses parity of palliative care is not always the case (Martinsson et al. 2018). A number of studies comparing groups of people with dementia against groups of people with cancer at EoL (Chen et al. 2017; Huang et al. 2017; Martinsson et al. 2018) found that those with dementia as well as cancer were more likely to have stays in hospital which involve distressing transfers, more likely to be in Intensive Care (ICU), more likely to have invasive procedures and less likely to receive hospice care than those with cancer and without dementia. Martinnson et al (2018) measured thirteen EoL quality care indicators and found that dementia patients were less likely to receive specific pain assessment.

The "gold standard" of pain management defines pain as whatever the patient says it is and specifies that associated assessment be continuous (Pasero and McCaffery 1999). It is often underdiagnosed and undertreated in patients with dementia at end of life (Abbey et al. 2004; Hanson et al. 2018), because they are both less able to communicate their needs (Aminoff and Adunsky 2006) and the assumption that all distress and problem behaviours result from the illness. Dening (2017) summarises outcomes of poor pain management as increased discomfort and distress, induced delirium and confusion and possible inappropriate prescribing of antipsychotic medications and sedatives. Caring for people with dementia is complex for both families (Aminoff 2005) and healthcare professionals. Behaviours induced by pain are often misinterpreted (Pryor and Clarke 2017) and not treated effectively resulting in distress and suboptimal palliative patient care (Aminoff and Adunsky 2006). 


\subsection{Rationale and objectives}

Other systematic reviews have looked at EoL care for people with dementia. The efficacy of a palliative care approach in dementia was investigated by Sampson et al. (2005). This identified one Random Control Trial (RCT) which did not address pain specifically (Ahronheim et al. 2000) and a second study which addressed discomfort rather than pain (Volicer et al. 1994). Other reviews have addressed the issue by including populations with dementia as comparator groups. A 2014 systematic review (Moens et al.) addressed the issue of EoL palliative care by comparing cancer with eight non-cancer related illnesses including dementia.

This systematic review examines the tools used in research to measure pain at end of life in people with dementia and provides an overview of research quality as well as addressing problems, issues and gaps. The PICOTS framework was used to develop the correct search strategy and establish eligibility criteria (Table 1).

Table 1 here

\section{Method}

\subsection{Design}

This review was conducted and reported using the Preferred Reporting items for Systematic Reviews and Meta-Analysis: the PRISMA statement (Moher et al. 2010) and registered with the PROSPERO database (PROSPERO CRD42019130806).

\subsection{Search methods}

A systematic search of the following databases was conducted: PubMed; (Ovid) Medline; (Ovid) Embase; (EBSCO Host) CINAHL Plus; (ISI) Web of Science; (Ovid) Psycinfo; (Ovid) PsycArticles; and Scopus. A grey literature search used Google Scholar. A number of reviews 
of Google Scholar concluded that while it is not suitable as a stand-alone systematic review resource it can be a powerful addition to database searches (Atkinson and Cipriani 2018; Haddaway et al. 2015). It is recommended to limit findings from Google Scholar to the first 200 to 300 results (Atkinson and Cipriani 2018; Haddaway et al. 2015). This was adopted for the current review. The search strategy for the Medline database is documented in Appendix 1. This search was adapted for use in the remaining databases searched.

\subsection{Study Selection}

Three reviewers were involved in study selection (GMcA, KN, GL) with initial searches completed by GMcA. Results were independently screened by title (GMcA and KN). Applied criteria included studies: available in English; published between 2000-2018 (ensuring examination of the most recent research); addressing dementia patients at end of life; and finally those concerned with pain assessment as part of palliative care. Searches were redone in February 2020 to identify more recent studies. Reviews, qualitative studies and case studies were excluded. Systematic reviews identified as part of the search were used for quality checking purposes and not included in the final narrative synthesis. There was no threshold population size as it was recognised that for ethical reasons this is a difficult area in which to conduct research. Following title screening, abstracts were extracted (GMcA) and independently reviewed (GMcA and $\mathrm{KN})$. Agreement rate was calculated as a percentage of the number of scripts agreed divided by the total number reviewed. GL screened the abstracts and consensus was reached between all three reviewers before proceeding to data extraction. The data extraction form was agreed by all three reviewers and GMcA performed data extraction. 


\subsection{Data Analysis}

Included studies were rated for quality using the Quality Assessment Tool for Quantitative Studies (QATQS) (National Collaborating Centre for Methods and Tools, 2008; Thomas et al. 2004). The tool uses six rated components using the definitions shown in Table 2. Studies with no weak and those with at least four strong ratings were judged to be strong. Studies with less than four strong ratings and one weak rating were considered moderate. Studies with two or more weak ratings are considered weak. Rating of the quality of included studies was conducted independently by GMcA and $\mathrm{KN}$, with differences identified and resolved through discussion. Consensus was reached between all three reviewers before proceeding.

Tools such as the Grading of Recommendations, Assessment, Development and Evaluation (GRADE) Working Group criteria (Atkins et al. 2004; Guyatt et al. 2008) define quality as the confidence in an estimate of effect drawn from a body of evidence. Because none of the studies using the same tool included a control group no effect sizes were derived. Fifteen studies used a tool to assess pain, with three applied in more than one study. However because of overlapping samples, differences in timing of measurement, or the manner in which results were reported it was not feasible to compare or grade them.

Table 2 here

\section{Results}

Initial searches produced 3033 paper for further scrutiny. Following removal of duplicates 1550 papers were examined, with a further 1244 removed after the paper titles were screened. Agreement between GMcA and $\mathrm{KN}$ at this stage was $84 \%$. Consensus was reached by discussion before abstract screening was performed independently. After abstract screening a further 236 studies were removed. Agreement between GMcA and $\mathrm{KN}$ at this stage was $80 \%$, 
with consensus reached after the inclusion of reviewer 3 (GL). Seventy full text articles were assessed for eligibility, with fifty-seven excluded and the remaining thirteen synthesised. Two studies were added when searches were rerun in 2020. Results are shown in Figure 1.

Figure 1 here

\subsection{Study characteristics}

Two excluded studies were systematic reviews (Moens et al. 2014; Sampson et al. 2005) which were used as a quality check for inclusion of other studies. Three studies reported on the same retrospective data (medical charts of nursing home residents diagnosed with dementia but who died from cancer) (Monroe and Carter 2010; Monroe et al. 2012; Monroe et al. 2013) Two of these studies used the same set of data (fifty-five people diagnosed with dementia and cancer) and the third analysed a subset of forty-eight of these. All three studies remained in this review but the number of participants was reduced by 103 reflecting the overlap. Table 3 shows the summary details of the studies included.

Table 3 - summary table here

No RCTs were conducted in this sample of studies and only one study used a quasiexperimental design (Verreault et al. 2018). The majority of studies were cross-sectional with eight out of the fifteen conducted retrospectively after death. A common method was to review medical charts after death.

Three studies had pain assessment for those at EoL with dementia as a primary focus (Monroe and Carter 2010; Monroe et al. 2012; Romem et al. 2015) with the remainder including pain as part of a wider focus on symptom management. In line with the PICOTS framework, 
characteristics of included studies are discussed in terms of participants, interventions, comparators, outcomes and setting.

\subsection{Participant characteristics}

Studies involved 6446 people with 1555 having dementia (of these sixty-six also had cancer).

Of the remaining, 5657 were receiving EoL care but their condition was not specified, ninetyone had cancer with no dementia and fifty-one had COPD. Most patients were female (highest percentage recorded 96\%) (Klapwijk et al. 2014). One study examining EoL patients on a long-term geriatric ward included a minority of females (39\%) (Aminoff and Adunsky 2005). Two studies reported an equal distribution of males and females (Romem et al. 2015; Soares et al. 2018). The overwhelming majority of studies took place in developed countries: six in the USA (Albrecht et al. 2013; Monroe and Carter 2010; Monroe et al. 2012; Monroe et al. 2013; Romem et al. 2015; Volicer et al. 2003); two in Belgium (Hermans et al. 2017; Vandervoort et al. 2013); and one each in Israel (Aminoff and Adunsky 2005), France (Nourhashemi et al. 2012), Netherlands (Klapwijk et al. 2014), England (Sampson et al. 2018), Brazil (Soares et al. 2018), Canada (Verreault et al. 2018) and New Zealand (Boyd et al. 2019).

\subsection{Intervention characteristics}

One study applied an intervention - a quasi-experiment comparing the effectiveness of an intervention versus usual care (Verreault et al. 2018): this took place in a long-term care facility with 193 participants, of whom ninety-seven received a five-component intervention, including training in use of the Pain Assessment Checklist for Seniors with Limited Ability to Communicate scale (PACSLAC) to assess pain. The ninety-six people in the control group received usual care. The groups were located in different long-term care facilities, two facilities 
implemented the intervention and two applied usual care. All residents included in the study were at either stage 'e, f' of the Functional Assessment Staging of Alzheimer's Disease (FAST) or had profiles ' 13 or 14' on the Functional Autonomy Measurement System iso-SMAF. Baseline comparisons were established by measuring Quality of Care (QOC) and Quality of Dying (QOD) over a six-month period before the study began. Only residents who died during the study period were included. The main focus of the study was not management of pain but rather the assessment of a multidimensional intervention, so pain was not reported as a standalone measure. Pain measurements were done using the PACSLAC, described below. They were then rolled into reporting of symptoms using the Symptom Management at the EoL in Dementia scale (SM-EOLD), also described below.

Table 4 here

Although not delivered as interventions the fourteen other studies did employ tools to measure symptoms. Table 4 shows the formal tools used in the studies, including details of the tools and measurement outcomes. Nine studies used a formal tool that assessed a range of symptoms, including pain (Aminoff and Adunsky 2005; Boyd et al. 2019; Hermans et al. 2017; Monroe and Carter 2010; Monroe et al. 2012; Monroe et al. 2013; Soares et al. 2018; Vandervoort et al. 2013; Volicer et al. 2003). Six studies used a formal tool to assess and report pain specifically (Klapwijk et al. 2014; Nourhashemi et al. 2012; Romem et al. 2015; Sampson et al. 2018; Soares et al. 2018; Verreault et al. 2018).

Six tools for measuring pain at the symptom-level were used: (1) the 9-item Symptom Management at the EoL in Dementia scale (SM-EOLD) (Boyd et al. 2019; Vandervoort et al. 2013; Volicer et al. 2003) - while scores are usually summed it can report pain as standalone 
(as in Vandervoort et al. 2013); (2) the 14-item Comfort Assessment in Dying at EoL in Dementia scale (CAD-EOLD), used in one study (Boyd et al. 2019), examines physical and emotional distress, wellbeing and symptoms associated with dying, with one item addressing pain - again, while scores are normally summed pain can be standalone (as in Vandervoort et al. 2013); (3) the Mini Suffering State Examination Scale (MSSE) used by one study (Aminoff and Adunsky 2005) addresses ten elements of suffering (including pain) - while the study did not report pain as measured by the scale, it did report the proportion of the population reporting pain in the last week of life; (4) the 17-item Discomfort Behaviour Scale (DBS), used by three studies derived from the same sample (Monroe and Carter 2010; Monroe et al. 2012; Monroe et al. 2013) addresses behaviours indicating pain or discomfort with outcomes reported as means; (5) the Palliative care Outcome Scale (POS), used by one study (Hermans et al. 2017), is a 10-item multidimensional scale covering physical, psychological, emotional and spiritual aspects of a person's life with the first eight (including a pain question) scored on a 5-point Likert scale ranging from no problem to overwhelming problem and findings reported as means - and pain scores reported separately; and finally (6) the Edmonton Symptom Assessment Scale (ESAS) used by one study (Soares et al. 2018) assesses nine symptoms, including pain (scored from 0-10) with a pain threshold for inclusion set from moderate to severe. This study reported pain as the proportion of people for whom pain was rated as moderate to severe.

We note that in terms of the psychometric properties for the purpose of measuring pain it is not possible to assess these scales as studies using them utilise overall scale scores and pain is only one item on each scale.

Four tools measured pain alone: (1) the Pain Assessment IN Advanced Dementia scale (PAINAD)-, used in three studies (Klapwijk et al. 2014; Romem et al. 2015; Sampson et al. 2018), is a 5-item measure each scored 0 to 2 , summing to $0-10$ with 2 or more indicating pain; 
(2) the Elderly Pain Caring Assessment scale (EPCA) used by one study (Nourhashemi et al. 2012) is an 8-item measure based on behaviours with each item scored from 0 -4 in increasing pain severity; (3) the PACSLAC (Verreault et al. 2018) comprises four subscales concerned with facial expression (13 items), social/personality/mood issues (12), activity/body movement (20) and physiological changes/eating sleeping changes/vocal behaviours (15 items) - here presence or absence of each item is noted over a period of time and scores are summed; and finally (4) one study (Albrecht et al, 2013) used the 5-item FLACC scale (Face, Legs, Activity, Cry, Consolability), each scored 0 to 2 , with pain either recorded on a rating scale (0-10) or categorised as not present, mild discomfort, moderate pain, or severe discomfort/pain or both.

With respect to their psychometric properties Goebel et al. (2019) found PAINAD to be a reliable and valid tool for pain screening in medical or surgical settings. However, a recent systematic review (Tapp et al. 2019) assessing pain assessment tools for non-verbal patients at EoL concluded that more work is needed to improve the scientific basis for testing and recommended a new tool be developed for this population. The EPCA assessment scale was assessed by Morello et al. (2007) was found to have good psychometric properties and was included in a 2016 systematic review (Husebo et al. 2016).

One meta-review (Lictner et al. 2014) of systematic reviews of pain assessment in dementia concluded that no tool could be recommended for use in this area due to a lack of rigorous testing of psychometric properties. However, Montoro-Lorite and Canalias-Reverter (2018) reviewed pain management protocols for dementia and recommended PACSLAC as effective in residential settings. No recent information could be found on the psychometric properties of the FLACC which was originally developed for use in children and was adapted as the PAINAD scale for use in adults (Montoro-Lorite and Canalias-Reverter 2018). 


\subsection{Comparator characteristics}

Only one study used a formal comparator group (Verreault et al. 2018); patients at terminal stage of dementia compared with residents in long-term care. One group received the intervention (as described above) and the other received usual care. Other studies incorporate less formal comparators. Most studies used records of people who had already died. The most frequently studied comparisons were between people with and without dementia (Albrecht et al. 2013; Boyd et al. 2019); people with dementia and people with cancer (Boyd et al. 2019; Martinsson et al. 2018; Romem et al. 2015; Soares et al. 2018); different types of care settings (Sampson et al. 2018); and people who died from COPD (Romem et al. 2015).

\subsection{Outcome characteristics}

The diversity of tools meant that a meta-analysis was impossible for this current review. Additionally, we could not determine which tools were useful in detecting pain reduction. Studies which used the same tool sometimes reported the results in different ways adding to the barriers to quantitative analysis. For example, the PAINAD scale was used in three studies: Klapwijk et al. (2104) reported outcomes as mean scores; while both Romem et al. (2015) and Sampson et al. (2018) reported outcomes as a percentage of people who made pain reports.

Six studies used four formal tools for the assessment of pain alone (Albrecht et al. 2013; Klapwijk et al. 2014; Nourhashemi et al. 2012; Romem et al. 2015; Sampson et al. 2018; Verreault et al. 2018). Outcomes were reported either as percentages of people who had pain, or as a mean of scores for the tool that was used. Albrecht et al. (2013) used the FLACC scale and reported that $19 \%$ of people reported pain (compared with $31 \%$ of a non-dementia comparison group). Klapwijk et al. (2014) used PAINAD and reported a mean pain score (1.9, 
$\mathrm{SD}=1.7)$. Nourhashemi et al. (2012) used the EPCA (0-32) and reported a mean score of 8.58 and a median score of 7. Romem et al. (2015) used PAINAD and reported outcomes as a percentage of people who had pain (with $75 \%$ of dementia patients noted as having clinically significant pain). Sampson et al. (2018) used PAINAD and reported outcomes as percentage of people who had pain (here $11 \%$ of people had pain at rest and $61 \%$ had pain when they moved). Verreault et al. (2018) carried out the intervention study and measured pain using PACSLAC. However, this study did not report PACSLAC scores or percentages of people who had pain, but reported pain scores combined as part of the SM-EOLD score which reported symptoms at an overall level.

Nine studies used formal tools for the assessment of a range of symptoms including pain. The DBS was used in three studies (Monroe and Carter 2010; Monroe et al. 2012; Monroe et al. 2013) each of which involved people with dementia who had died from cancer. The 2012 and 2013 studies reported mean DBS scores of 7 (range 3-48), while the 2010 study reported mean scores $3.54(\mathrm{SD}=5.49)$ and $10.81(\mathrm{SD}=14.42)$ for Caucasian and African American patients respectively.

The SM-EOLD scale was used in three studies (Boyd et al. 2019; Vandervoort et al. 2013; Volicer et al. 2003). Volicer et al. (2003) did not report pain as a stand-alone result. Vandervoort et al. (2013) reported pain as mean scores taken in the last month and the last week of life - which for the last month of life was 1.9 on a range from 0 to 5 and for the last week was 2.0. Boyd et al. (2019) recorded reported pain during the last month of life, -with a mean of 0.6 and range $0-5$. This study was also the only study to use the CAD-EOLD scale to measure pain in the last week of life. It was reported as a stand-alone measure. The mean score was 2.3 with range 1 to 3. 
The MSSE scale was used in one study (Aminoff and Adunsky, 2005). Pain scores were not reported. The POS-Staff version was used in one study (Hermans et al. 2017), with outcomes reported as mean and median scores - here the mean was 1 (range=0-4), with the median=0.5. The final study, which addressed pain as part of a wider assessment of symptoms, used the EDMS (Soares et al. 2018). Thirty-four percent of residents with dementia reported pain, compared with $57 \%$ of people who had cancer.

\subsection{Setting characteristics}

Six studies used data of residents or ex-residents in nursing homes (Hermans et al. 2017; Klapwijk et al. 2014; Monroe and Carter, 2010; Monroe et al. 2012; Monroe et al. 2013; Vandervoort et al. 2013). Additional care facility settings included an acute care facility (Soares et al. 2018), long-term care facilities (Boyd et al. 2019; Verreault et al. 2018) and a hospice (Albrecht et al. 2013), Volicer et al. (2003) and Sampson et al. (2018) compared experiences between home care and institutional care. Three studies had a hospital setting (Aminoff and Adunsky 2005; O’Shea et al. 2015; Romen et al. 2015).

\subsection{Limitations of the literature}

There are major limitations in the reviewed studies, including use of medical records to collect data or third parties such as relatives or medical staff. Given the nature of dementia it is difficult to recruit people into studies. Additionally, sample size calculations were not provided and appeared underpowered to detect differences. 
These limitations had implications for the quality of the evidence. No RCTs were available. No studies were rated as high quality, ten were assessed as weak and five assessed as of moderate quality (Boyd et al. 2019; Nourhashemi et al. 2012; Romem et al. 2015; Sampson et al. 2018; Verreault et al. 2018). Overall grading of evidence could not be performed due to the lack of the same or harmonised tools used in the studies. Only one tool specifically designed to measure pain alone was used in more than one study, PAINAD (Klapwijk et al. 2014; Romem et al. 2015; Sampson et al. 2018) and outcomes were not presented in the same way in all three studies.

\section{Discussion}

This is the first systematic review to address issues of pain assessment in the dementia population specifically at end-of-life and how available tools are deployed. The primary purpose was to assess pain measurement in studies of end of life care for people with dementia.

Pain and symptom control are crucial to a good death (Holdsworth 2015; Smith 2000; Morrison and Meier 2000) with physical pain being a central element of suffering (Aminoff and Adunsky 2006). Although four tools that measure pain specifically were identified (PACSLAC, PAINAD, EPCA, and FLACC) and six identified which tools measure a full range of symptoms including pain (SM-EOLD, CAD-EOLD, MSSE, DBS, POS-Staff and ESAS) what is not known and what needs to be understood is the effectiveness of these tools in managing pain in the dementia population. There is a clear need to improve the quality of research that is conducted in pain measurement and management in dementia. Recommendations are set out in Table 5.

Table 5 about here. 


\subsection{Conclusion}

Future research should include rigorous methodology which will permit evaluation of pain measurement and management for those with dementia at end of life. There are clear recruitment and ethical barriers to overcome in end of life research which increase when severe cognitive impairment is a major factor. To address methodological issues presented in the current body of research, study designs are required that allow the use of formal tools to be applied and assessed while addressing ethical considerations inherent in the topic domain. While RCTs may be problematic, Verreault et al. (2018) showed the possibility of implementing a quasi-experimental design which incorporated training and application of the comprehensive PACSLAC tool. Many people with dementia live in nursing or care homes at the end of life which provides opportunity for intervention studies to be conducted. Small sample sizes can be counteracted by introducing intervention designs across multiple care homes. The formal use of pain assessment tools can contribute to people at EoL having their pain needs met, and the interplay between research and practice can be used to increase momentum for improvement in both.

\section{Conflict of interest}

All authors declare they have no conflicts of interest.

\section{Acknowledgements and Funding:}

This work was supported by funding from the Administrative Data Research Centre-NI (ADRC-NI) funded by the Economic and Social Research Council (ESRC). 


\section{References}

Abbey J, Piller N, Bellis AD, Esterman A, Parker D, Giles L, Lowcay B. 2004. The Abbey pain scale: a 1-minute numerical indicator for people with end-stage dementia. Int. J. Palliat. Nurs. 10: 6-13.

Albrecht JS, Gruber-Baldini AL, Fromme EK, McGregor JC, Lee DS, Furuno JP. 2013. Quality of hospice care for individuals with dementia. J Am Geriatr Soc. 61:, 1060-1065. Alzheimer's Society. 2014. Dementia 2014: Opportunity for change. [Internet] [Cited 12 Apr 2019]. Available from:

https://www.alzheimers.org.uk/sites/default/files/migrate/downloads/dementia_2014_opportu nity_for_change.pdf

Aminoff BZ. 2005. Overprotection phenomenon with dying dementia patients. Am J Hosp Palliat Care, 22: 4.

Aminoff BZ, Adunsky A. 2005. Dying dementia patients: too much suffering, too little palliation. Am J Hosp Palliat Care. 22: 344-348.

Aminoff BZ, Adunsky A. 2006. Their last 6 months: suffering and survival of end stage dementia patients. Age Ageing. 35: 597-601.

Ahronheim JC, Morrison RS, Morris J, Baskin S, Meier DE. 2000. Palliative care in advanced dementia: a randomized controlled trial and descriptive analysis. J. Palliat. Med. 3: 265-273.

Atkins D, Best D, Briss PA. 2004. coll.; GRADE Working Group. Grading quality of evidence and strength of recommendations. BMJ. 328: 1490.

Atkinson LZ, Cipriani A. 2018. How to carry out a literature search for a systematic review: a practical guide. BJPsych Advances. 24: 74-82.

Boyd M, Frey R, Balmer D, Robinson J, McLeod H, Foster S, ... Gott M. 2019. 
End of life care for long-term care residents with dementia, chronic illness and cancer: prospective staff survey. BMC Geriatr. 19: 137.

Chen YH, Ho CH, Huang CC, Hsu YW, Chen YC, Chen PJ, ... Wang JJ. 2017. Comparison of healthcare utilization and life-sustaining interventions between elderly patients with dementia and those with cancer near the end of life: A nationwide, population-based study in Taiwan. Geriatr Gerontol Int. 17: 2545-2551.

Dening KH, 2017. Supporting people with dementia at end of life. Res Nurs Health. 19: 688-692.

Dyer SM, Harrison SL, Laver K, Whitehead C, Crotty M. 2018. An overview of systematic reviews of pharmacological and non-pharmacological interventions for the treatment of behavioral and psychological symptoms of dementia. Int Psychogeriatr. 30 : 295-309.

Goebel JR, Ferolito M, Gorman N. 2019. Pain screening in the older adult with delirium. Pain Manag Nurs. 20: 519-525.

Guyatt GH, Oxman AD, Vist GE, Kunz R, Falck-Ytter Y, Alonso-Coello P, Schünemann HJ. 2008. GRADE: an emerging consensus on rating quality of evidence and strength of recommendations. BMJ 336: 924-926.

Haddaway NR, Collins AM, Coughlin D, Kirk S. 2015. The role of Google Scholar in evidence reviews and its applicability to grey literature searching. PloS One. 10: e0138237. Hanson LC, Kistler CE, Lavin K, Gabriel SL, Ernecoff NC, Lin FC, ... Mitchell SL. 2018. Triggered Palliative Care for Late-stage Dementia: a Pilot Randomized Trial. J Pain Symptom Manag. 57: 10-19.

Hermans K, Cohen J, Spruytte N, Van Audenhove C, Declercq A. 2017. Palliative care needs and symptoms of nursing home residents with and without dementia: A crosssectional study. Geriatr Gerontol Int. 17: 1501-1507. 
Holdsworth LM. 2015. Bereaved carers' accounts of the end of life and the role of care providers in a 'good death': A qualitative study. Palliative Medicine. 29: 834-841.

Horgas AL, Yoon SL, Grall M. 2008. Pain management. Evidence-Based Geriatric Nursing Protocols for Best Practice, 4th ed. USA(NY): Springer Publishing Company 246-67 p.

Huang HK, Hsieh JG, Hsieh CJ, Wang YW. 2017. Do cancer patients with dementia receive less aggressive treatment in end-of-life care? A nationwide populationbased cohort study. Oncotarget. 8: 63596.

Husebo BS, Achterberg W, Flo E. 2016. Identifying and managing pain in people with Alzheimer's disease and other types of dementia: a systematic review. CNS drugs. 30: 481-497.

Klapwijk MS, Caljouw MA, van Soest-Poortvliet MC, van der Steen JT, Achterberg WP, 2014. Symptoms and treatment when death is expected in dementia patients in long-term care facilities. BMC Geriatr. 14: 99.

Lichtner V, Dowding D, Esterhuizen P, Closs SJ, Long AF, Corbett A, Briggs M. 2014. Pain assessment for people with dementia: a systematic review of systematic reviews of pain assessment tools. BMC geriatrics 14: 138.

Martinsson L, Lundström S, Sundelöf J. 2018. Quality of end-of-life care in patients with dementia compared to patients with cancer: A population-based register study. PloS One. 13: e0201051.

Moens K, Higginson IJ, Harding R, Brearley S, Caraceni A, Cohen J, ... Linden K. 2014. Are there differences in the prevalence of palliative care-related problems in people living with advanced cancer and eight non-cancer conditions? A systematic review. J Pain Symptom Manag 48: 660-677.

Moher D, Liberati A, Tetzlaff J, Altman DG. 2010. PRISMA Group. Preferred 
reporting items for systematic reviews and meta-analyses: the PRISMA statement. Int J Surg 8: $336-41$.

Monroe TB, Carter MA, 2010. A retrospective pilot study of African-American and Caucasian nursing home residents with dementia who died from cancer. J Pain Symptom Manag. 40: e1-e3.

Monroe TB, Carter MA, Feldt KS, Dietrich MS, Cowan RL. 2013. Pain and hospice care in nursing home residents with dementia and terminal cancer. Geriatr Gerontol Int. 13:1018-1025.

Monroe T, Carter M, Feldt K, Tolley B, Cowan RL. 2012. Assessing advanced cancer pain in older adults with dementia at the end-of-life. J Adv Nurs. 68: 2070-2078. Montoro-Lorite M, Canalias-Reverter M. 2018. Advanced dementia pain management protocols. Enferm. Clin. (English Edition). 28: 194-204.

Morello R, Jean A, Alix M, Sellin-Peres D, Fermanian J. 2007. A scale to measure pain in non-verbally communicating older patients: The EPCA-2: Study of its psychometric properties. Pain. 133: 87-98.

Morrison RS, Meier DE. 2004. Palliative care. N Engl J Med. 350: 2582-2590. National Collaborating Centre for Methods and Tools [Internet]. 2008. Hamilton (ON): Quality Assessment Tool for Quantitative Studies. McMaster University; [Cited 12 Apr 2019]. Available from https://www.nccmt.ca/knowledge-repositories/search/14. Nourhashemi F, Gillette S, Cantet C, Stilmunkes A, Saffon N, Rouge-Bugat ME, ... Rolland Y. 2012. End-of-life care for persons with advanced Alzheimer disease: design and baseline data from the ALFINE study. J Nutr Health Aging. 16: 457-461. O’Shea E, Timmons S, Kennelly S, Siún AD, Gallagher P, O’Neill D. 2015. Symptom assessment for a palliative care approach in people with dementia admitted to acute hospitals: results from a national audit. J Geriatr Psych Neur. 28: 255-259. 
Pasero C, McCaffery M. 1999. Pain: clinical manual (Vol. 9). St. Louis: Mosby.

Pryor C, Clarke A. (2017). Nursing care for people with delirium superimposed on dementia. Nurs. Older People 29: 18-21.

Romem A, Tom SE, Beauchene M, Babington L, Scharf SM, Romem A. 2015.

Pain management at the end of life: A comparative study of cancer, dementia, and chronic obstructive pulmonary disease patients. J Palliat Med. 29: 464-469.

Sampson EL, Candy B, Davis S, Gola AB, Harrington J, King M, ... Omar RZ. 2018. Living and dying with advanced dementia: a prospective cohort study of symptoms, service use and care at the end of life. J Palliat Med. 32: 668-681.

Sampson EL, Ritchie CW, Lai R, Raven PW, Blanchard MR. 2005. A systematic review of the scientific evidence for the efficacy of a palliative care approach in advanced dementia. Int Psychogeriatr. 17: 31-40.

Seow H, O’Leary E, Perez R, Tanuseputro P. 2018. Access to palliative care by disease trajectory: a population-based cohort of Ontario decedents. BMJ Open. 8: e021147. Smith R, 2000. A good death: an important aim for health services and for us all. BMJ. 320: 129.

Soares LGL, Japiassu AM, Gomes LC, Pereira R, Peçanha C, Goldgaber T. 2018. Prevalence and intensity of dyspnea, pain, and agitation among people dying with late stage dementia compared with people dying with advanced cancer: a single-center preliminary study in Brazil. Ann Palliat Med. 7: 437-443.

Tapp D, Chenacher S, Gérard NPA, Bérubé-Mercier P, Gelinas C, Douville F, Desbiens JF. 2019. Observational Pain Assessment Instruments for Use With Nonverbal Patients at the End-of-life: A Systematic Review. J Palliat Med. 34: 255-266.

Thomas BH, Ciliska D, Dobbins M, Micucci S. 2004. A process for systematically 
reviewing the literature: providing the research evidence for public health nursing interventions. Worldviews Evid Based Nurs. 1: 176-184.

Vandervoort A, Van den Block L, van der Steen JT, Volicer L, Vander Stichele R, Houttekier D, Deliens L. 2013. Nursing home residents dying with dementia in Flanders, Belgium: a nationwide postmortem study on clinical characteristics and quality of dying. $\mathrm{J}$ Am Med Dir Assoc. 14: 485-492.

Verreault R, Arcand M, Misson L, Durand PJ, Kroger E, Aubin M, ... Grégoire A. 2018.

Quasi-experimental evaluation of a multifaceted intervention to improve quality of end-oflife care and quality of dying for patients with advanced dementia in long-term care institutions. J Palliat Med. 32: 613-621.

Volicer L, Collard A, Hurley A, Bishop C, Kern D, Karon S. 1994. Impact of special care unit for patients with advanced Alzheimer's disease on patients' discomfort and costs. J Am Geriatr Soc. 42: 597-603.

Volicer L, Hurley AC, Blasi ZV. 2003. Characteristics of dementia end-of-life care across care settings. Am J Hosp Palliat Care. 20: 191-200. 
Table 1. The PICOTS framework as applied to the research question

\begin{tabular}{|l|l|}
\hline Category & Criteria \\
\hline Population of interest & People with a diagnosis of dementia who are at end-of-life \\
\hline Intervention of interest & Tools used for the assessment and treatment of pain \\
\hline Comparator & $\begin{array}{l}\text { RCTs are not expected to be found for this population, however possible } \\
\text { comparators are populations with another terminal illness at EoL }\end{array}$ \\
\hline Outcome of interest & Pain measurement \\
\hline Timing & Publication date 2000 or later \\
\hline Setting & Any setting - home, nursing home, hospice, hospital \\
\hline
\end{tabular}


Table 2. Quality assessment components and ratings.

\begin{tabular}{|c|c|c|c|}
\hline Component & Strong & Moderate & Weak \\
\hline Selection bias & $\begin{array}{l}\text { Very likely to be representative } \\
\text { of the target population and } \\
\text { greater than } 80 \% \text { participation } \\
\text { rate }\end{array}$ & $\begin{array}{l}\text { Somewhat likely to be } \\
\text { representative of the target } \\
\text { population and greater than } \\
60-79 \% \text { participation rate }\end{array}$ & $\begin{array}{l}\text { All other responses or } \\
\text { not stated }\end{array}$ \\
\hline Design & RCT and CCT & $\begin{array}{l}\text { Cohort analytic, case-control, } \\
\text { cohort or interrupted time } \\
\text { series }\end{array}$ & $\begin{array}{l}\text { All other designs or } \\
\text { design not stated }\end{array}$ \\
\hline Confounders & $\begin{array}{l}\text { Controlled for at least } 80 \% \text { of } \\
\text { confounders }\end{array}$ & $\begin{array}{l}\text { Controlled for } 60-79 \% \text { of } \\
\text { confounders }\end{array}$ & $\begin{array}{l}\text { Confounders not } \\
\text { controlled for or not } \\
\text { stated }\end{array}$ \\
\hline Blinding & $\begin{array}{l}\text { Blinding of outcome assessor } \\
\text { and study participants to } \\
\text { intervention status }\end{array}$ & $\begin{array}{l}\text { Blinding of either outcome } \\
\text { assessor or study participants }\end{array}$ & $\begin{array}{l}\text { Outcome assessor and } \\
\text { study participants are } \\
\text { aware of intervention } \\
\text { status/and or research } \\
\text { question }\end{array}$ \\
\hline $\begin{array}{l}\text { Data collection } \\
\text { and methods }\end{array}$ & Tools are valid and reliable & $\begin{array}{l}\text { Tools are valid but reliability } \\
\text { not described }\end{array}$ & $\begin{array}{l}\text { No evidence of validity } \\
\text { or reliability }\end{array}$ \\
\hline $\begin{array}{l}\text { Withdrawals } \\
\text { and dropouts }\end{array}$ & $\begin{array}{l}\text { Follow-up rate of } 80 \% \text { or more } \\
\text { of participants }\end{array}$ & $\begin{array}{l}\text { Follow-up rate of } 60-79 \% \text { of } \\
\text { participants }\end{array}$ & $\begin{array}{l}\text { Follow-up rate of }<60 \% \\
\text { of participants or } \\
\text { withdrawals and } \\
\text { dropouts not described }\end{array}$ \\
\hline
\end{tabular}


Table 3. Summary of studies

\begin{tabular}{|c|c|c|c|c|}
\hline Author, year & Country & Design & Sample and setting & Main focus of study \\
\hline $\begin{array}{l}\text { Volicer et al., } \\
2003\end{array}$ & US & $\begin{array}{l}\text { Retrospective survey } \\
\text { (after death) }\end{array}$ & $\begin{array}{l}\text { Family caregivers of } 154 \text { people who died from } \\
\text { dementia. Both home care and institutional care. } \\
\text { Care receivers: } 55 \% \text { female, mean age } 81.2 \pm 7.5\end{array}$ & $\begin{array}{l}\text { To promote establishment of evidence for making } \\
\text { policy recommendations. To describe characteristics } \\
\text { of enf-of-life (EoL) care in different settings. To } \\
\text { develop three scales designed specifically to measure } \\
\text { end-of-life care outcomes in dementia }\end{array}$ \\
\hline $\begin{array}{l}\text { Aminoff et al., } \\
2005\end{array}$ & Israel & Prospective cohort & $\begin{array}{l}\text { End stage dementia patients }(\mathrm{n}=71) \text { admitted to a } \\
\text { long-term geriatric ward of a tertiary medical centre. } \\
39.4 \% \text { female. Mean age } 82.9 \pm 8\end{array}$ & $\begin{array}{l}\text { To evaluate the level of suffering in dementia patients } \\
\text { during their final hospital stay }\end{array}$ \\
\hline $\begin{array}{l}\text { Monroe et al., } \\
2010\end{array}$ & US & $\begin{array}{l}\text { Retrospective chart } \\
\text { review (after death) }\end{array}$ & $\begin{array}{l}\text { Nursing home resident }(\mathrm{n}=55) \text { who died from cancer } \\
\text { with a diagnosis of dementia also. } 54.5 \% \text { female. } \\
\text { Mean age } 86.4 \pm 7.84\end{array}$ & $\begin{array}{l}\text { To explore the differences between African American } \\
\text { and Caucasian nursing home residents pain } \\
\text { management at EoL }\end{array}$ \\
\hline $\begin{array}{l}\text { Nourhashemi et } \\
\text { al., } 2012\end{array}$ & France & Prospective cohort & $\begin{array}{l}\text { Alzheimer's patients }(n=112) \text { in the severe stage of } \\
\text { the illness in hospital. } 76.8 \% \text { female. Mean age } \\
84.03 \pm 6.96\end{array}$ & $\begin{array}{l}\text { To describe the design of the ALFINE study and the } \\
\text { characteristics of the recruited cohort }\end{array}$ \\
\hline $\begin{array}{l}\text { Monroe et al., } \\
2012\end{array}$ & US & $\begin{array}{l}\text { Retrospective chart } \\
\text { review (after death) }\end{array}$ & $\begin{array}{l}\text { Nursing home residents }(\mathrm{n}=48) \text { with mild to severe } \\
\text { dementia. } 54 \% \text { female. Mean age } 86 \pm 8\end{array}$ & $\begin{array}{l}\text { To assess advanced cancer pain in older adults with } \\
\text { dementia at EoL }\end{array}$ \\
\hline $\begin{array}{l}\text { Albrecht et al., } \\
2013\end{array}$ & US & Cross-sectional survey & $\begin{array}{l}\text { Hospice patients with dementia }(n=450) \text { and without } \\
\text { dementia }(n=4261) .55 \% \text { female. Mean age } 78 \pm 0.3 \text {. } \\
\text { Patients with dementia: } 61 \% \text { female, mean age } 85 \pm \\
0.7\end{array}$ & $\begin{array}{l}\text { To quantify differences in quality measures between } \\
\text { individuals in hospice with and without dementia }\end{array}$ \\
\hline $\begin{array}{l}\text { Monroe et al., } \\
2013\end{array}$ & US & $\begin{array}{l}\text { Retrospective chart } \\
\text { review (after death) }\end{array}$ & $\begin{array}{l}\text { Nursing home residents }(\mathrm{n}=55) \text { with dementia who } \\
\text { died from cancer. } 54.5 \% \text { female. Mean age } 86.4 \pm 7.8\end{array}$ & $\begin{array}{l}\text { To examine the associations between hospice } \\
\text { enrolment, dementia severity and pain among nursing } \\
\text { home residents who died from advanced cancer }\end{array}$ \\
\hline
\end{tabular}


Pain tools in EoL care for dementia 2

\begin{tabular}{|c|c|c|c|c|}
\hline Author, year & Country & Design & Sample and setting & Main focus of study \\
\hline $\begin{array}{l}\text { Vandervoort et } \\
\text { al., } 2013\end{array}$ & Belgium & $\begin{array}{l}\text { Retrospective cross- } \\
\text { sectional (after death) }\end{array}$ & $\begin{array}{l}\text { Nursing home residents who died from dementia } \\
(n=198) .61 .5 \% \text { female. Mean age } 86.7\end{array}$ & $\begin{array}{l}\text { To study how many deceased nursing home residents } \\
\text { had dementia in Flanders, Belgium, to describe their } \\
\text { clinical characteristics and quality of dying }\end{array}$ \\
\hline $\begin{array}{l}\text { Klapwijk et al., } \\
2014\end{array}$ & Holland & $\begin{array}{l}\text { Prospective and } \\
\text { retrospective cohort }\end{array}$ & $\begin{array}{l}\text { Nursing home residents with dementia at the EoL } \\
(n=24) .96 \% \text { female. Mean age } 91\end{array}$ & $\begin{array}{l}\text { To describe the incidence and course of observed } \\
\text { symptoms and treatment in people with dementia in } \\
\text { the last days before their expected death }\end{array}$ \\
\hline $\begin{array}{l}\text { Romem et al., } \\
2015\end{array}$ & US & $\begin{array}{l}\text { Retrospective chart } \\
\text { review (after death) }\end{array}$ & $\begin{array}{l}\text { Patients with a terminal illness admitted to hospital, } \\
\text { COPD }(n=51,64.7 \% \text { female, mean age } 75.8 \pm 10.7) \text {, } \\
\text { cancer }(n=47,44.7 \% \text { female, mean age } 73.7 \pm 13.4) \text {, } \\
\text { dementia }(n=48,50 \% \text { female, mean age } 85.9 \pm 7.1)\end{array}$ & $\begin{array}{l}\text { To explore if patients with dementia and COPD } \\
\text { achieve less optimal pain control than patients with } \\
\text { end-stage cancer }\end{array}$ \\
\hline $\begin{array}{l}\text { Hermans et al., } \\
2017\end{array}$ & Belgium & Cross-sectional & $\begin{array}{l}\text { Nursing home residents anticipated to be in the last } \\
\text { year of life ( } \mathrm{n}=109,68 \% \text { female, mean age } 87 \\
\text { years). } 55 \% \text { were diagnosed with dementia. } \\
\text { Descriptive s were not reported by diagnoses }\end{array}$ & $\begin{array}{l}\text { To describe palliative care needs and symptoms of } \\
\text { older adults anticipated to be in the last year life in } \\
\text { Flemish nursing homes and evaluate whether these } \\
\text { palliative care needs differ between residents with and } \\
\text { without dementia }\end{array}$ \\
\hline $\begin{array}{l}\text { Sampson et al., } \\
2018\end{array}$ & England & Prospective cohort & $\begin{array}{l}\text { People with advanced dementia living at home and } \\
\text { in nursing homes }(\mathrm{n}=85) \text {. The majority were women } \\
(\% \text { not reported), mean age } 85 \text { years }\end{array}$ & $\begin{array}{l}\text { To describe the course of physical and psychological } \\
\text { symptoms in those with advanced dementia. To } \\
\text { examine health and social care service utilisation. To } \\
\text { describe the care received at EoL }\end{array}$ \\
\hline $\begin{array}{l}\text { Soares et al., } \\
2018\end{array}$ & Brazil & $\begin{array}{l}\text { Retrospective chart } \\
\text { review (after death) }\end{array}$ & $\begin{array}{l}\text { People in a post-acute care facility }(n=108) \text { who had } \\
\text { died from dementia }(n=57,49 \% \text { female, mean age }= \\
\text { 86) or from cancer }(n=54,64 \% \text { female, mean age }= \\
\text { 73) }\end{array}$ & $\begin{array}{l}\text { To estimate the prevalence and intensity of dyspnoea, } \\
\text { pain and agitation among people dying with late stage } \\
\text { dementia compared with those dying with advanced } \\
\text { cancer }\end{array}$ \\
\hline
\end{tabular}


Pain tools in EoL care for dementia 3

\begin{tabular}{|l|l|l|l|l|}
\hline Author, year & Country & Design & Sample and setting & Main focus of study \\
\hline $\begin{array}{l}\text { Verreault et al., } \\
2018\end{array}$ & Canada & Quasi-experimental & $\begin{array}{l}\text { People living in a long-term care facility (193). } \\
\text { Ninety-seven received a 5-component intervention } \\
\text { including pain monitoring (76.3\% female, mean age } \\
=88.9 \pm 9.4) .96 \text { received usual care (69.7\% female, } \\
\text { mean age }=88.1 \pm 6.2)\end{array}$ & $\begin{array}{l}\text { To assess a multidimensional and multidisciplinary } \\
\text { intervention to improve EoL care in advanced } \\
\text { dementia in long-term care facilities }\end{array}$ \\
\hline Boyd et al., 2019 & New Zealand & $\begin{array}{l}\text { Retrospective chart } \\
\text { review (after death) }\end{array}$ & $\begin{array}{l}\text { Residents in 61 long-term care facilities (n=286) } \\
\text { who had died from cancer (17\%), dementia (49\%), } \\
\text { both cancer and dementia (4\%) and other chronic } \\
\text { illness (30\%). For those who died from dementia } \\
60 \% \text { were female. Mean age was not reported. For } \\
\text { those with dementia 16\% were 80 years old or } \\
\text { younger, 54\% were aged between 81-91 years and } \\
30 \% \text { were 92 years old and above }\end{array}$ & $\begin{array}{l}\text { To compare symptoms before death of those in long- } \\
\text { term care with cancer, dementia and other chronic }\end{array}$ \\
& & &
\end{tabular}


Table 4. Details of pain tools and measurements

\begin{tabular}{|c|c|c|c|c|c|}
\hline Author, year & Pain Assessment Tool & Duration of measurement & Pain Assessed By & Pain Score - people with dementia & Study Quality \\
\hline $\begin{array}{l}\text { Volicer et al., } \\
2003\end{array}$ & $\begin{array}{l}\text { No tool that assessed pain } \\
\text { independently. SM-EOLD is a } \\
\text { symptom management scale which } \\
\text { has } 1 \text { measure out of } 9 \text { addressing } \\
\text { pain, with the scores summed. }\end{array}$ & Not detailed & Not detailed & Not detailed & Weak \\
\hline $\begin{array}{l}\text { Monroe et al., } \\
2010\end{array}$ & Discomfort Behaviour Scale & Assessed after death & $\begin{array}{l}\text { Reports of pain in medical } \\
\text { records }\end{array}$ & $\begin{array}{l}\text { Mean DBS score } \\
\text { Caucasian patients: } 3.54(\mathrm{SD}=5.49) \\
\text { African American patients: } \\
10.81(\mathrm{SD}=14.42)\end{array}$ & Weak \\
\hline $\begin{array}{l}\text { Nourhashemi et } \\
\text { al., } 2012\end{array}$ & $\begin{array}{l}\text { Elderly Pain Caring Assessment } \\
\text { Scale }\end{array}$ & Not detailed & Caregiving staff & $\begin{array}{l}\text { Mean score }=8.58 \\
\text { Median score }=7\end{array}$ & Moderate \\
\hline $\begin{array}{l}\text { Monroe et al., } \\
2012\end{array}$ & Discomfort Behaviour Scale & Assessed after death & $\begin{array}{l}\text { Reports of pain in medical } \\
\text { records }\end{array}$ & Mean DBS score $=7(3-48)$ & Weak \\
\hline $\begin{array}{l}\text { Albrecht et al., } \\
2013\end{array}$ & $\begin{array}{l}\text { FLACC scale (Face, Legs, Activity, } \\
\text { Cry, Consolability) }\end{array}$ & Once at last assessment & Caregiving staff & $\begin{array}{l}\text { Pain reports } \\
19 \% \text { of those with dementia } \\
31 \% \text { of those without dementia }\end{array}$ & Weak \\
\hline
\end{tabular}


Pain tools in EoL care for dementia 2

\begin{tabular}{|c|c|c|c|c|c|}
\hline Author, year & Pain Assessment Tool & Duration of measurement & Pain Assessed By & Pain Score - people with dementia & Study Quality \\
\hline $\begin{array}{l}\text { Monroe et al., } \\
2013\end{array}$ & Discomfort Behaviour Scale & Assessed after death & $\begin{array}{l}\text { Reports of pain in medical } \\
\text { records }\end{array}$ & Mean DBS score $=7(3-48)$ & Weak \\
\hline $\begin{array}{l}\text { Vandervoort et } \\
\text { al., } 2013\end{array}$ & $\begin{array}{l}\text { No tool that assessed pain } \\
\text { independently. SM-EOLD is a } \\
\text { symptom management scale which } \\
\text { has } 1 \text { measure out of } 9 \text { addressing } \\
\text { pain, with the scores summed }\end{array}$ & $\begin{array}{l}\text { Last month of life, last week } \\
\text { of life }\end{array}$ & Nursing staff & $\begin{array}{l}\text { Pain was extracted and reported alone } \\
\text { Mean score }=1.9(0-5) \text { in last month of } \\
\text { life } \\
\text { mean score }=2(0-5) \text { in last week of life }\end{array}$ & Weak \\
\hline $\begin{array}{l}\text { Klapwijk et al., } \\
2014\end{array}$ & $\begin{array}{l}\text { Pain Assessment in Advanced } \\
\text { Dementia scale }\end{array}$ & Last week of life & Care physicians & Mean score $=1.9($ SD 1.7) & Weak \\
\hline $\begin{array}{l}\text { Romem et al., } \\
2015\end{array}$ & $\begin{array}{l}\text { Pain Assessment in Advanced } \\
\text { Dementia scale }\end{array}$ & $\begin{array}{l}48 \text { hours after admission to } \\
\text { hospice }\end{array}$ & Hospice staff & $\begin{array}{l}75 \% \text { of dementia patients had pain } \\
\text { reports of clinically significant pain }\end{array}$ & Moderate \\
\hline $\begin{array}{l}\text { Hermans et al., } \\
2017\end{array}$ & $\begin{array}{l}\text { Palliative Care Outcome scale - } \\
\text { staff version. } 1 \text { question addresses } \\
\text { pain }\end{array}$ & Once & Caregivers & $\begin{array}{l}\text { mean score }=1.1(0-4) \\
\text { median score }=0.5(0-4)\end{array}$ & Weak \\
\hline $\begin{array}{l}\text { Sampson et al., } \\
2018\end{array}$ & $\begin{array}{l}\text { Pain Assessment in Advanced } \\
\text { Dementia scale }\end{array}$ & $\begin{array}{l}\text { Every } 4 \text { weeks till } 9 \text { months or } \\
\text { death }\end{array}$ & Research staff & $\begin{array}{l}11 \% \text { of patients reported pain at rest } \\
61 \% \text { reported pain on movement }\end{array}$ & Moderate \\
\hline $\begin{array}{l}\text { Soares et al., } \\
2018\end{array}$ & $\begin{array}{l}\text { Edmonton Symptom Assessment } \\
\text { System which includes pain as one } \\
\text { measurement. Numeric rating from } \\
0 \text { (none) to } 10 \text { (worst). } \\
\text { Pain intensity measured as } \\
\text { percentage of patients with } \\
\text { symptoms rated as moderate to } \\
\text { severe }\end{array}$ & Last 3 days of life & Registered nurses. & $\begin{array}{l}\text { Pain reports rated moderate to severe } \\
34 \% \text { of dementia patients } \\
57 \% \text { of patients with cancer }\end{array}$ & Weak \\
\hline
\end{tabular}


Pain tools in EoL care for dementia 3

\begin{tabular}{|c|c|c|c|c|c|}
\hline Author, year & Pain Assessment Tool & Duration of measurement & Pain Assessed By & Pain Score - people with dementia & Study Quality \\
\hline $\begin{array}{l}\text { Verreault et al., } \\
2018\end{array}$ & $\begin{array}{l}\text { Pain Assessment Checklist for } \\
\text { Seniors with Limited Ability to } \\
\text { Communicate (PACSLAC). }\end{array}$ & $\begin{array}{l}\text { Twice a day until } 1 \text { year or } \\
\text { death. }\end{array}$ & Nursing staff & $\begin{array}{l}\text { Pain not reported alone, rolled into SM- } \\
\text { EOLD score }\end{array}$ & Moderate \\
\hline $\begin{array}{l}\text { Boyd et al., } \\
2019\end{array}$ & $\begin{array}{l}\text { SM-EOLD - last month of life } \\
\text { CAD-EOLD - last week of life }\end{array}$ & $\begin{array}{l}\text { Last month of life } \\
\text { Last week of life }\end{array}$ & $\begin{array}{l}\text { Registered nurses through } \\
\text { survey after death }\end{array}$ & $\begin{array}{l}\text { Last month of death: people with } \\
\text { dementia, SM-EOLD mean score in } \\
\text { range } 0-5=0.6 \\
\text { Last week of death: people with } \\
\text { dementia, CAD-EOLD mean score in } \\
\text { range } 1-3=2.3\end{array}$ & Moderate \\
\hline
\end{tabular}


Table 5. Recommendations

\begin{tabular}{|c|c|}
\hline Recommendation & Detail \\
\hline $\begin{array}{l}\text { Guidelines or protocols for the study of pain assessment at } \\
\text { end of life for people with dementia }\end{array}$ & $\begin{array}{l}\text { While it is recognised that ethical considerations prohibit the use of RCTs in this group, this } \\
\text { systematic review has shown that the use of a quasi-experimental design is possible in an ethical way } \\
\text { and allows comparison of interventions versus usual care. }\end{array}$ \\
\hline Retrospective studies & $\begin{array}{l}\text { The majority of studies used to assess pain measurement have been retrospective, after the death of } \\
\text { the patient. Implementing a prospective study design would ensure a more robust approach. }\end{array}$ \\
\hline A pain assessment tool & $\begin{array}{l}\text { The ideal outcome is to identify and standardise a tool which is effective and robust in the assessment } \\
\text { of pain in this group in a research setting. In order to study outcomes in a meaningful way, tools } \\
\text { should report pain measurement in a manner which allows comparison. This would facilitate } \\
\text { measurement and meta-analysis. }\end{array}$ \\
\hline Use of a comparison group & $\begin{array}{l}\text { Studying the application of pain assessment tools is in itself valuable in this group. However in order } \\
\text { to ensure that this assessment is of the same level as a group with established good quality EoL care, } \\
\text { a comparison with people with cancer is recommended. }\end{array}$ \\
\hline Measurement of pain after assessment and intervention & $\begin{array}{l}\text { There is a lack of data on what happens to pain levels after pain has been assessed and mitigation } \\
\text { applied. Study design should ensure that pain in re-assessed after pain medication has been } \\
\text { administered. Therefore studies can report if the pain medication has reduced the pain and provided } \\
\text { comfort. }\end{array}$ \\
\hline Measurement of health inequalities & $\begin{array}{l}\text { There is a dearth of research which addresses health inequalities in this group. Is pain assessment at } \\
\text { end of life for those with dementia affected, for example, by ethnicity. }\end{array}$ \\
\hline
\end{tabular}




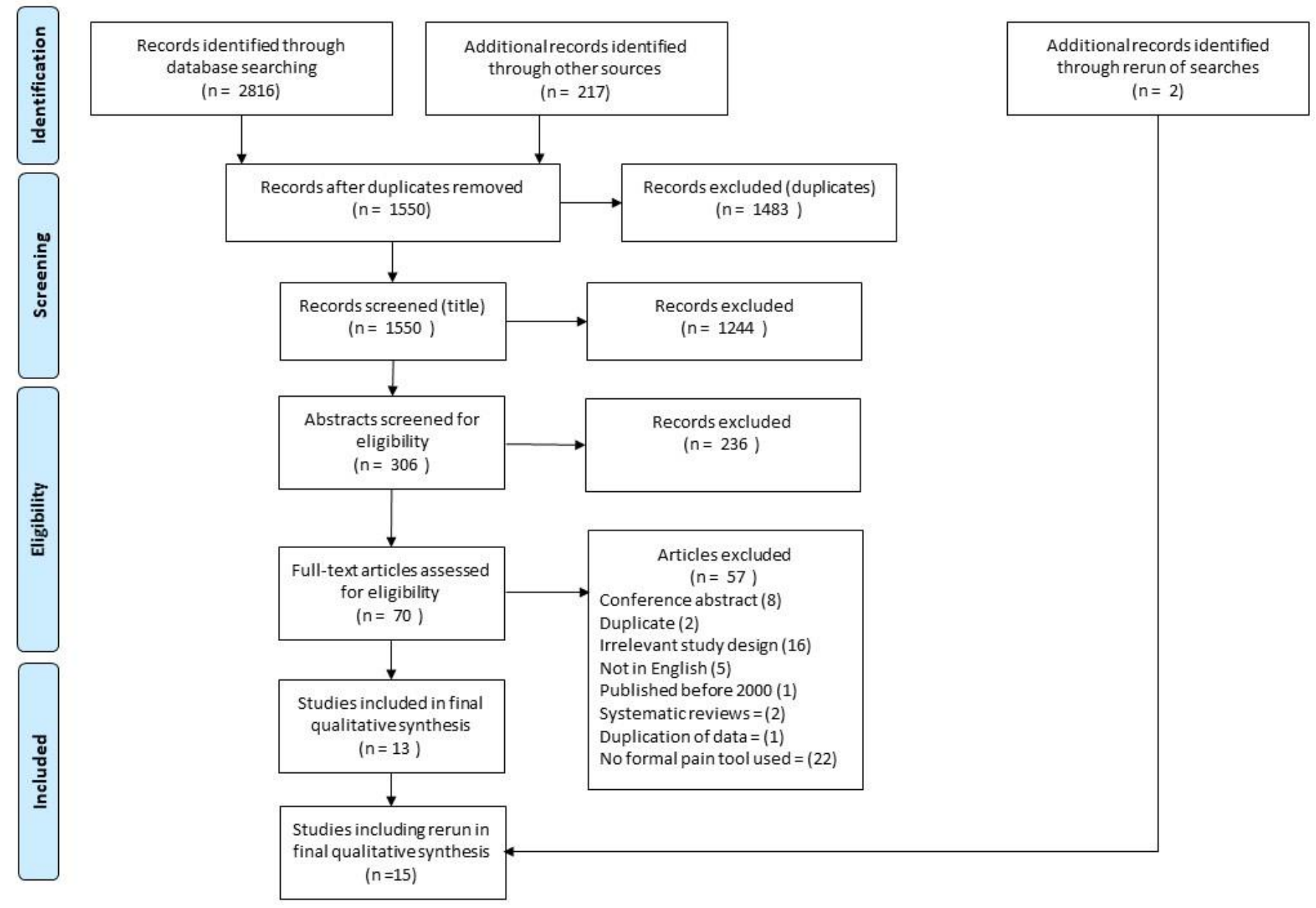

Figure 1. Flow diagram of results 


\section{Appendix 1}

\begin{tabular}{|c|c|}
\hline Medline Search Strategy & $\begin{array}{l}\text { Hits Retrieved } \\
\text { 11th December } 2018\end{array}$ \\
\hline $\begin{array}{l}\text { 1.exp dementia/ } \\
\text { 2.dementia*.mp. } \\
\text { 3. "frontotemporal dementia*".mp. } \\
\text { 4. "vascular dementia*".mp. } \\
\text { 5. alzheimer*.mp. } \\
\text { 6."lewy bod*".mp. } \\
\text { 7. } 1 \text { or } 2 \text { or } 3 \text { or } 4 \text { or } 5 \text { or } 6 \\
\text { 8. exp terminal care/ } \\
\text { 9. "end-of-life car*".mp. } \\
\text { 10. "EOL car*".mp. } \\
\text { 11.exp palliative therapy/ } \\
\text { 12. "palliat*".mp. } \\
\text { 13. "palliat* car*".mp. } \\
\text { 14."palliat* medic*".mp. } \\
\text { 15. "palliat* treat*".mp. } \\
\text { 16."palliat* medic*".mp. } \\
\text { 17."terminal car*".mp. } \\
\text { 18."end-of-life treat*".mp. } \\
\text { 19."EOL treat*".mp. } \\
\text { 20. } 8 \text { or } 9 \text { or } 10 \text { or } 11 \text { or } 12 \text { or } 13 \text { or } 14 \text { or } 15 \text { or } 16 \text { or } 17 \text { or } 18 \text { or } 19 \\
\text { 32. } 7 \text { and } 20 \text { and } 31 \\
\text { 21. exp PAIN MEASUREMENT/ or exp PAIN MANAGEMENT/ or } \\
\text { exp PAIN/ } \\
\text { 22. analgesi*.mp. } \\
\text { 23. "analgesi* test*".mp. } \\
\text { 24. "pain management*".mp. } \\
\text { 25. pain.mp. } \\
\text { 26. "physical suffering*".mp. } \\
\text { 27. "pain measurement*".mp. } \\
\text { 28. "pain assessment*".mp. } \\
\text { 29. "pain treatment*".mp. } \\
\text { 30. exp Analgesics/ } \\
\text { 31. } 21 \text { or } 22 \text { or } 23 \text { or } 24 \text { or } 25 \text { or } 26 \text { or } 27 \text { or } 28 \text { or } 29 \text { or } 30 \\
\text { (1) }\end{array}$ & 296 \\
\hline
\end{tabular}

